\title{
Socio-economic, Health and Working Conditions of Child Beedi Rollers in Beedi Industry
}

\author{
Monica Munjial Singh \\ Associate Professor, University Institute of Emerging Areas in Social Sciences, Centre \\ for Social Work, Panjab University, Chandigarh, India
}

Tel: 91-941-778-1428. E-mail: mona13mch@gmail.com

Mohammad Amiri (Corresponding author)

PhD Research Scholar, University Institute of Emerging Areas in Social Sciences, Centre for Social Work, Panjab University, Chandigarh, India

Tel: 91-978-061-2892. E-mail: mohammad.amiri.qiau@gmail.com

\begin{abstract}
Sherry Sabbarwal
Professor, University Institute of Emerging Areas in Social Sciences, Centre for Social Work, Panjab University, Chandigarh, India.
\end{abstract}

Tel: 91-981-400-7991. Email: sherrysabbarwal@gmail.com

Received: October 21, 2017 Accepted: December 17, 2017 Published: December 19, 2017

doi: 10.5296/jsss.v5i1.12328 URL: http://doi.org/10.5296/jsss.v5i1.12328

\begin{abstract}
Beedi manufacturing industry in India, is a highly labour-intensive and predominantly it is an unorganized sector. The beedi rolling function is generally done by women and child labourers who have no other means of financial earning. Child labourers are weak segments of Indian unorganized labour force. This study has been done in Solapur city of Maharashtra state in India. This city is important and famous for power loom industry and beedi industry also. Through the study an attempt has been made to highlight the health problems faced by child beedi rollers. This study also focuses on the factors which force children to work in beedi manufacturing industry and assesses literacy level of the child beedi rollers. The results of the study show that socio-economic condition of majority of the selected child beedi
\end{abstract}


rollers is very poor and majority of them are facing various deceases due to constant exposure to tobacco dust and unhygienic working conditions at work place. Most of them have not completed their primary education.

Keywords: Beedi industry, Child beedi rollers, Child labour, Health problems, Working conditions

\section{Introduction}

In India, tendu leaves are used for rolling beedies with shredded tobacco. Majority of children and women are engaged in beedi rolling activity in beedi manufacturing factories situated in different parts of Indian cities. The All India Beedi Cigar and Tobacco Workers Federation estimates women and children comprise about $90 \%$ to $95 \%$ of the beedi manufacturing labour force. The labourers engaged in beedi rolling activity belong to economically and socially backward segments of Indian society. Beedi manufacturing industry is one of the major industries where concentration of child labourers is very-very high. The Child Labour (Prohibition and Regulation) Act, 1986 bans employment of child labourers in hazardous industries like beedi manufacturing factory. Section 3 of this Act, includes a special provision which permits children to work in the beedi manufacturing process with the aid of the family. Beedi manufacturing organizations exploit this special provision by giving work to families, who in turn also engage their children in the beedi manufacturing process. Children are used by their parents to earn, therefore to some extent it has taken away the control on prevention of child labour.

The main objective of the present study is to present a current scenario of health, socio-economic and working conditions of child beedi rollers in beedi manufacturing factories of Solapur city.

\section{Review of Literature}

Mukharjee et al. (2014) have conducted a study with a view to highlight the health profile of beedi workers in Murshidabad district of West Bengal. Through the study authors have pointed out that, majority of beedi workers are economically weak without having education. Authors have observed that, due to frequent contact with tobacco dust, many workers are suffering from health related disorders, such as Tuberculosis, lung cancer etc. Women beedi rollers suffered from irregular menstruation and other pregnancy problems. Through the study authors have pointed out the fact that the health problems faced by the beedi rollers are tremendous.

Surendra (2001) has presented state wise distribution of working children in India according to the census 1971, 1987 and 1991. The main aim of the study was to highlight the living and working conditions of beedi workers in general and child labours in particular. Through the study author has highlighted the social and economic realities that force the children to work as a beedi roller at an early age. Author has also observed that, the beedi rolling work is the only source of earning for the child labours' families daily needs. Author has also attempted to provide information about working and living conditions of child beedi rollers. Author has concluded that, low earnings in beedi rolling occupation have created a stress on beedi rollers to roll more and more beedies which they fulfilled by engaging their children to help in increasing family income. 


\section{Macrothink}

Journal of Social Science Studies

ISSN 2329-9150

2018, Vol. 5, No. 1

Padole (2014) has focused on the child labours in beedi rolling households in Gondia district of Maharashtra. Through the study author has highlighted the problem of exploitation of child beedi rollers. The main objective of the study is to examine the working condition of child beedi rollers at their work place and also highlighted the nature and forms of exploitation and moral abuse to which they are subjected. Author has suggested that, there should be comparative assessments of the ability of different NGO's with respect to their work towards beedi rolling factories. Author has also suggested that, the rehabilitation related initiatives of the NGO's and government should be assessed in further studies.

Dube and Mohandoss (2013) have highlighted the important factors which are responsible for children engaging in beedi factories. In the opinion of author, sub-contracting, poor economic condition, vulnerability of children, ignorance of parents are some of the major factors which are responsible for children engaging in beedi factories. Author has suggested that, detail survey should be conducted in various parts of Indian cities with a view to mapping the socio-economic details of children beedi rollers. In the opinion of author, there should be strict implementation of minimum wages and social security benefits to the beedi rollers and there should be regular monitoring abuse girl child working in beedi work involving the protection from sexual offences.

\section{Significance of the Study}

The child labourers working in beedi manufacturing factories are facing several health and socio-economic problems like poor financial condition, illiteracy, insufficient nutritious food, ineptness of parents etc. Through some past studies has been observed that, the socio-economic and health conditions of child labourers are very bad. The beedi rolling activity causes many health problems to the child labourers. Researcher is interested to understand about the health, socio-economic and working conditions of child labourers. The present study will be helpful to the NGO's which are engaged in the development activities, pertaining to child labour in unorganized sector like beedi factories. The child labourers who are engaged in beedi rolling, are below poverty line, and thus it is important to improve the living conditions and good education. It is also important to collect qualitative as well as quantitative information about child beedi rollers in Solapur city, where the employment of child labour is widespread and hidden because of many loopholes present in the current Indian legislation related to child labour and the predominance of households in the beedi rolling occupation.

\section{Objective of the Study}

On the basis of significance of the study, following objectives have been formulated:

1) To highlight the major factors which lead children to work in beedi factory.

2) To present the health conditions reported by the selected child labourers.

3) To highlight the problems faced by child labourers at work place.

4) To understand the parents' awareness about the Child Labour Prohibition Act.

\section{Research Methodology}

The present study is very short and exploratory in nature. Structured interview schedule has been used to collect the data regarding the socio-economic, health and working conditions of child beedi rollers. 


\subsection{Selection of Sample}

118 child beedi rollers (both male and female) have been randomly selected from various beedi manufacturing factories in purposively selected Solapur city of Maharashtra for this study. All the selected child labourers are in the age group of 9 years to 14 years. Research methodology consists of filed survey by using purposive sampling method.

\subsection{Limitations of the Study}

The present study is limited to highlight the socio-economic, health and working conditions of child beedi rollers from the factories of Solapur only.

\section{Results and Discussion}

The following table indicates the gender wise distribution of selected child beedi rollers:

Table 1. Gender wise distribution of child beedi rollers

\begin{tabular}{lll}
\hline Gender & Frequency & Percentage \\
\hline Male Child beedi rollers & 46 & $39 \%$ \\
Female Child beedi rollers & 72 & $61 \%$ \\
Total & 118 & $100 \%$ \\
\hline
\end{tabular}

The above table reveals that in the selected sample $61 \%$ of the child beedi rollers are female and $39 \%$ are male.

Table 2. Educational status of child beedi rollers

\begin{tabular}{lll}
\hline Educational status & Frequency & Percentage \\
\hline Illiterate & 08 & $7 \%$ \\
Primary level of education & 69 & $58 \%$ \\
Secondary level of education & 41 & $35 \%$ \\
Total & 118 & $100 \%$ \\
\hline
\end{tabular}

Among the total sample of child beedi rollers $7 \%$ child beedi rollers are illiterate. The child beedi rollers who have completed their primary education or dropped out constituted $58 \%$ of the total sample. $35 \%$ child beedi rollers had got some part of secondary level education. Out of the 41 students, most of them had dropped out before completing Class X. Thus, this shows that, the education status of the selected child beedi rollers is very low; therefore they are forced to accept this type of unskilled and low pay job. 
Table. 3. Monthly income of selected child beedi rollers

\begin{tabular}{lll}
\hline Income Range & Frequency & Percentage \\
\hline Below 1000 Rs. & 29 & $25 \%$ \\
Rs. 1000 to 3000 Rs. & 65 & $55 \%$ \\
Above Rs. 3000 & 24 & $20 \%$ \\
Total & 118 & $100 \%$ \\
\hline
\end{tabular}

Income of the people is strongly correlated to their socio-economic conditions. Good earnings allows them to maintain their standard of living. As per the information provided by the selected child beedi rollers, majority of child beedi rollers (55\%) are earning Rs. 1000 to Rs. 3000 per month, 20\% respondents are earning above Rs. 3000 per month. Around 25\% child beedi rollers get a meagre monthly income of less than Rs. 1000.

The following table indicates the daily working hours of selected child beedi rollers.

Table. 4. Daily working hours of the child beedi rollers

\begin{tabular}{lll}
\hline Duration of work & Frequency & Percentage \\
\hline Less than 8 hours & 13 & $11 \%$ \\
8 hours to 10 hours & 61 & $52 \%$ \\
10 hours to 12 hours & 36 & $30 \%$ \\
Above 12 hours & 08 & $7 \%$ \\
Total & 118 & $100 \%$ \\
\hline
\end{tabular}

The above table reveals that, majority of child beedi rollers (52\%) are working for 8 hours to 10 hours daily, $30 \%$ are working for 10 hours to 12 hours and around $7 \%$ child beedi rollers are working for more than 12 hours. Only $11 \%$ child beedi rollers are working less than 8 hours daily. This indicates that, working hours are too high for children of age group found in the selected sample.

The following table indicates the major influencing factors which leads children to work in beedi factories: 
Table 5. Influencing factors which lead children to work in beedi factories (Multiple Response)

\begin{tabular}{lll}
\hline Factors & Frequency & Percentage \\
\hline Weak Financial Condition & 118 & $100 \%$ \\
Easy Source of livelihood & 97 & $82 \%$ \\
No interest in Education/ Educational & 57 & $48 \%$ \\
deprivation & & \\
Other factors & 46 & $39 \%$ \\
\hline
\end{tabular}

There are many influencing factors which lead children to accept the beedi rolling work in beedi manufacturing factories. As per the collected primary information from the child beedi rollers, $100 \%$ have stated that, weak financial condition of their families push them into this occupation, they have to help their parents for maintaining standard of living. Apart from this, there is no requirement of formal training for beedi rolling and can be carried out at any time in a day. This is also one of the reasons of engaging children in beedi rolling work. This is an easy source of livelihood, was stated by $82 \%$ of the child beedi rollers. Educational deprivation and no interest in education are also important influencing factors which push children in the beedi rolling work. Indebtedness addictions of parents and their unemployment are also some of the factors caused for children involvement in beedi rolling work, stated by $39 \%$ child beedi rollers.

To highlight on the health condition of selected child beedi rollers is also one of the major objectives of the present study. The facts related to health conditions, based on the information provided by the child beedi rollers are provided in the following table.

Table 6. Health condition of child beedi rollers

\begin{tabular}{lll}
\hline Symptoms of Ill-health & Frequency & Percentage \\
\hline Headache and Body pain & 103 & $87 \%$ \\
Cough and Tuberculosis/Asthama & 07 & $6 \%$ \\
Breathlessness and giddiness & 05 & $4 \%$ \\
Stomach related problems & - & - \\
Other Symptoms & 03 & $3 \%$ \\
Total & 118 & $100 \%$ \\
\hline
\end{tabular}

Due to monotonous and repetitive nature of beedi rolling activity, it leads to severe stress on body, therefore, majority of child beedi rollers $(87 \%)$ are facing the problem of headache and body pain. Due to continuously working in beedi factories and inhaling tobacco dust, $6 \%$ child beedi rollers are facing problems like cough, tuberculosis, asthama, etc. $4 \%$ child beedi 
rollers are facing the problem of breathlessness and giddiness. $3 \%$ are facing the problem like back strain, spondylitis, swelling of lower limbs etc.

Beedi manufacturing industry is predominantly an unorganized sector and therefore, beedi rollers are facing several problems pertaining to their health and working conditions. The information provided by the selected child beedi rollers regarding the problems faced by them is presented in the following table.

Table 7. Problems faced by child beedi rollers (Multiple Response)

\begin{tabular}{lll}
\hline Problems & Frequency & Percentage \\
\hline High rejection rate of manufactured beedies & 109 & $92 \%$ \\
No timely payment & 83 & $70 \%$ \\
Heavy work load & 87 & $74 \%$ \\
Unhygienic workplace & 99 & $84 \%$ \\
Exploitation by employer/contractor & 104 & $88 \%$ \\
Low bargaining power & 111 & $94 \%$ \\
\hline
\end{tabular}

High rate of rejection of manufactured beedies due to poor quality of raw materials is one of the major problems faced by $92 \%$ child beedi rollers, child beedi rollers are easily becoming victims for this. $74 \%$ child beedi rollers are working for more than 10 hours in a day due to heavy work load. $70 \%$ child beedi rollers have stated that, they are not getting their payment on time. $84 \%$ child beedi rollers have stated that, they have to work in unhygienic conditions - there is no provision of toilets, restrooms, place for having lunch etc. $84 \%$ have stated that, they are often exploited by their contractors or employer by giving them heavy work load, in lower wages etc. It is found that, $94 \%$ child beedi rollers are not having bargaining power and they have to compulsorily accept this type of occupation because they do not have any alternate source of earning.

It is important to know about the parents' awareness about the Child Labour Prohibition Acts implemented in India, therefore, researcher has asked about the prohibition Acts, to the parents of child beedi rollers. The information provided by them is presented in the following table:

Table 8. Parents' awareness about Child Labour Prohibition Act

\begin{tabular}{lll}
\hline Description & Frequency & Percentage \\
\hline Yes & 06 & $5 \%$ \\
No & 112 & $95 \%$ \\
Total & 118 & $100 \%$ \\
\hline
\end{tabular}




\section{Macrothink}

As per the information provided by the parents of selected child beedi rollers, $95 \%$ of them are not aware about the Child Labour Prohibition Act, only 5\% of parents are aware about the act.

\section{Major Findings}

1) As per the selected sample of child beedi rollers in Solapur, majority of them are female child beedi rollers.

2) It is found that, majority of child beedi rollers are not having enough education to be able to find some other skilful occupation. Their monthly income is mainly ranging in between Rs. 1000 to Rs. 3000, which is not enough for fulfilling daily needs of their families.

3) It is found that, majority of child beedi rollers are working for more than 10 to 12 hours in a day due to heavy work load and for that they are not getting any extra payment from their contractor or manufacturer.

4) Due to vulnerability of children, beedi manufacturers or contractors are often preferred to employ children for beedi rolling work, so that they can avoid the legal measures, such as, minimum payment, leaves and other benefits. Apart from this, there are many other factors which push children in beedi rolling activity. These factors are - poor financial condition of family, parents' ignorance towards the children's education, sometimes children also don't have any interest in academic activities and they turn to this occupation. Rolling of beedi is not skilful job and does not require any special training, therefore, as per the children's point of view, this job is an easy source of livelihood for them.

5) It is found that, manufacturers or contractors deliberately reject the beedies rolled by children, so that they have to pay low amount of money to the child beedi rollers. Apart from this there are many other problems faced by child beedi rollers, like working in unhygienic place, no timely payment, exploitation by employer or contractor, etc.

6) Due to lower education levels child beedi rollers are not aware about the various legislations related to child labour and they are having very low bargaining power.

7) It is also observed that, majority of child beedi rollers are currently facing many health related issues due to continuous contact with tobacco dust and working in unhygienic conditions. Due to handling of tobacco flakes and inhaling of tobacco dust they are facing the problems like headache, body pain, back strain, spondylitis, swelling of lower limbs etc.

8) It is found that, parents of selected child beedi rollers are also not aware about the legislation of child labour.

9) It is found that, beedi manufacturing factories in Solapur city are dominated by women and child workers as against the general scenario in which male workers dominate beedi manufacturing factories in India.

\section{Suggestions}

1) It is suggested that assessment related to health problems being faced by child beedi rollers should be done continuously.

2) It is suggested that, there should be frequent investigation by the law enforcement agencies. 


\section{Macrothink}

Journal of Social Science Studies

ISSN 2329-9150

2018, Vol. 5, No. 1

3) There should be active intervention by government agencies and NGO's, with an aim of development and rehabilitation of child beedi rollers.

4) There should be assurance by the government, that every child beedi roller will get proper education.

5) There should be active role of NGO's in implementing various welfare programmes for child beedi rollers and they should undertake small projects to improve the overall quality of life of the child beedi rollers.

\section{References}

Aghi, M. B., \& Gopal, M. (2001). Exploiting women and children-India's beedi industry. Lifeline, 6, 8-10.

Dube, Y., \& Mohandoss, G. (1995). A study on child labour in Indian Beedi industry. Agenda, 6 , $7 . \quad$ Retrieved from http://www.softtown.in/aplabour/documents/child_labour/Child_Labour_In_Indian_Beedi_In dustry.pdf

Mukherjee, M., Goswami, A., Mazumdar, D., \& Pal, B. (2014). A study on health profile of beedi workers in West Bengal, India. International Journal of Advanced Research in Management and Social Sciences, 3(8), 17-25. Retrieved from http://garph.co.uk/IJARMSS/Aug2014/2.pdf

Ministry of Labour and Employment. (2011). 17th Report of Standing Committee on Labour: Welfare of Beedi Workers. Presented to Lok-Sabha in 2011.

Padole, A. B. (2014). Exploitation of bidi rolling child labour. International Journal of Humanities, Arts, Medicine and Sciences, 2(8), 67-75.

Sen, V. (2007). Effects of working condition on health of beedi workers: a study of Sagar District of Madhya Pradesh. Environment drinking water and public health: problems and future goals. New Delhi, India: Daya Publishing House, 132-49.

Surendra, P. (2001). Current Trends in Child Labour: A case study of Beedi Industry in Tikamgrah, M. P. Centre for Education and Communication, Working paper.

Umadevi, B., Swarna, M., Padmavathi, P., Jyothi, A., \& Reddy, P. P. (2003). Cytogenetic effects in workers occupationally exposed to tobacco dust. Mutation Research/Genetic Toxicology and Environmental Mutagenesis, 535(2), 147-154. https://doi.org/10.1016/S1383-5718(02)00291-7

\section{Copyright Disclaimer}

Copyright for this article is retained by the author(s), with first publication rights granted to the journal.

This is an open-access article distributed under the terms and conditions of the Creative Commons Attribution license (http://creativecommons.org/licenses/by/3.0/). 